\title{
High-level yielding of insecticidal crystal proteins and field testing of a genetically modified Bacillus thuringiensis biopesticide WG-001
}

\author{
Lin $\mathrm{Li}^{*}$, Zhengyu Shu, Zongze Shao, Ziniu $\mathrm{Yu}^{*}$ \\ State Key Laboratory of Agricultural Microbiology, College of Life Science and Technology, Huazhong \\ Agricultural University, Wuhan 430070, China \\ * Corresponding authors. Tel: +86 27 87280802; Fax: +86 27 87393882. E-mail addresses: \\ lilin@mail.hzau.edu.cn (L.L.) and yz41@ mail.hzau.edu.cn (Z. Y.)
}

\begin{abstract}
A genetically modified (GM) Bacillus thuringiensis strain WG-001 was constructed and prepared as a biopesticide for field trial of its biocontrol efficacy and for assessing the ecological impact on the indigenous microflora. Using a TnpI-mediated site-specific recombinant strategy, a crylAcl0 and an additional p20 gene were transferred into $B$. thuringiensis wild-type strain YBT-1520 while all of the heterologous antibiotic resistance genes were selectively eliminated. The resultant engineered strain, WG-001, exhibited a two-fold increase of the total Cry proteins and an approximately $25 \%$ increase of lepidopterancidal potency in fermentation compared to its parent strain, and it was also given a distinct trait to allow tracking of its appearance using simple polymerase chain reaction verification of $p 20$ and cryl-like genes. In the cotton field, released WG-001 biopesticide showed a limited aerial dissemination capability and dispersal range, and did not establish a population in the soils or on the cotton leaves of the field. There was no evidence supporting the significant biological influence of WG-001 on the indigenous microflora. These results demonstrate that the likelihood of risks of released WG-001 to nontarget organisms in the cotton fields was limited by the low survival of the introduced strain.
\end{abstract}

Keywords: Genetically modified Bacillus thuringiensis; pesticide; fate; cotton field

\section{Introduction}

Bacillus thuringiensis has been widely exploited as a microbial control agent since 1950s (Jouzani et al. 2017, Li et al. 2017, Melo et al. 2016), and in the recent decade, by making combinations of insecticidal genes that did not occur naturally, or introducing these genes into alternative host bacteria, a variety of genetically modified (GM) derivatives were created for extending the uses of the insecticidal bacteria (Federici 2005, Li and Yu 2012, Palma et al. 2014). However, while the applications of B. thuringiensis have proved to be successful in terms of target pest control and reduction of the use of chemical insecticides, concerns about the safety of $B$. thuringiensis-derived GM biopesticides have never appeased. The fate of introduced GM bacteria and possible effects on the indigenous microbial community are normally considered to be the key ecological issues. So far, although many studies have primarily concluded that the field-released GM bacteria tended to remain confined to the applied area, did not persist or appear to transfer genes to indigenous microorganisms, and had similar basic biological functions in natural and laboratory settings (Lawler 2017, Siegwart et al. 2015, Singh and Dubey 2016, Viebahn et al. 2003, Yaqoob et al. 2016), the genetic exchanges between $B$. thuringiensis and its related or unrelated species have been frequently observed (Thomas et al. 2001, Venter and Bohn 2016, Vilas-Boas et al. 2002). Since there may be different adverse effects caused by different GM bacteria, a case-by-case approach for assessing the GM bacteria should be taken.

Although an antibiotic resistance marker can certainly provide a simple and inexpensive means to monitor the introduced strain in mixed populations, it is unlikely that a GM B. thuringiensis strain containing a heterologous antibiotic resistance gene would receive approval and acceptance for its release in the environment. For this reason, Sanchis et al. (Sanchis et al. 1997) developed a site-specific recombination system to selectively eliminate the foreign antibiotic resistance genes from the GM strains. This approach should meet the regulation requirements for the development of such a GM $B$. thuringiensis strain for commercial use.

P20 is a helper protein that was identified in $B$. thuringiensis subsp. israelensis strains (Dervyn et al. 1995), and is essential for Cry protein yield in subsp. israelensis, including Cyt1 A (Wu and Federici 1993, 1995) and Cry4A (Wu and Federici 1995). Moreover, it has been shown to affect Cry protein accumulation in other subspecies (Shao et al. 2001). In the present study, a 20 was introduced into $B$. thuringiensis wildtype strain YBT-1520 by using the TnpI-mediated site-specific recombination strategy. The resultant GM strain, WG-001, is free of foreign plasmidbearing antibiotic resistance genes, and it also provides a useful tracking tag that allows PCR amplification of $p 20$ since a previous investigation has shown that there is no homologous gene of $p 20$ in YBT-1520 (Sun et al. 2000), and no investigation has revealed the synchronous appearance of $p 20$ and cryllike genes in a naturally occurring $B$. thuringiensis strain to date. The effects of P20 on the yield of the insecticidal crystal proteins in WG-001 and the insecticidal activities against Heliothis armigera larva were examined, and its fate in a cotton field microcosm and the potential biological impact on the 
indigenous microflora was preliminarily assessed.

\section{Materials and Methods}

\section{Bacterial strains, genes, plasmids and growth conditions}

The bacterial strains and plasmids used are listed in Table 1. Generally, B. thuringiensis subsp. kurstaki strain YBT-1520 was used as the recipient for generation of GM WG-001 strain. Escherichia coli DH-5 $\alpha$ was used as a host for constructing various recombinant plasmids. Plasmid pBMB20-2 provided the gene resources of $p 20$ and promoter sequences of crylC. The plasmid pBMB1233 containing one resolution site (res), crylAclO and the truncated sitespecific recombinase gene (tnpI') of transposon Tn4430 (Wu et al. 2000), and plasmid pBMB1229 containing the other res and $B$. thuringiensis replicon oril030, were used as the parent vectors for constructing pBMB1803, pBMB1805 and their derivatives, $\mathrm{pBMB} 1808, \mathrm{pBMB} 1811$ and $\mathrm{pBMB} 1812$.

B. thuringiensis strains bearing recombinant plasmids were grown in Luria-Bertani (LB) medium at $30^{\circ} \mathrm{C}$ in the presence of $25 \mu \mathrm{g} \mathrm{ml}^{-1}$ of erythromycin, unless otherwise stated. E. coli transformed cells were routinely grown at $37{ }^{\circ} \mathrm{C}$ in LB broth containing 100 $\mu \mathrm{g} \mathrm{m}{ }^{-1}$ of ampicillin. A selective medium containing $0.2 \%$ of yeast extract, $0.1 \%$ of glucose, $0.005 \%$ $\mathrm{MgSO}_{4} \cdot 7 \mathrm{H}_{2} \mathrm{O}, 0.01 \%$ of $\mathrm{CaCl}_{2}, 2 \%$ of agar and $0.1 \mathrm{mg}$ $\mathrm{ml}^{-1}$ nystatin was used for plating the culturable bacteria from the soil and leaf samples, whereas a medium containing $0.1 \mathrm{~g} \mathrm{ml}^{-1}$ of glucose, $0.05 \mathrm{~g} \mathrm{ml}^{-1}$ of peptone, $1 \mu \mathrm{g} \mathrm{ml}{ }^{-1}$ of $\mathrm{KH}_{2} \mathrm{PO}_{4}, 0.5 \mu \mathrm{g} \mathrm{ml} \mathrm{m}^{-1}$ of $\mathrm{MgSO}_{4} \cdot 7 \mathrm{H}_{2} \mathrm{O}, 2 \%$ of agar and $25 \mu \mathrm{g} \mathrm{ml} \mathrm{m}^{-1}$ of chloramphenicol was used to culture the filamentous fungi and yeast isolates from soil samples. For mass production of WG-001, an optimized fermentation medium was used, with various concentrations of soybean meal, cornmeal, fish meal, peptone, yeast extract, $\mathrm{KH}_{2} \mathrm{PO}_{4}, \mathrm{MgSO}_{4} \cdot 7 \mathrm{H}_{2} \mathrm{O}$ and $\mathrm{CaCO}_{3}$.

Table 1. Bacterial strains and plasmids used in this study.

\begin{tabular}{|c|c|c|}
\hline Strain/Plasmid & Relevant characteristic $(\mathrm{s})^{\mathrm{a}}$ & Reference(s) \\
\hline \multicolumn{3}{|c|}{ Bacillus thuringiensis } \\
\hline YBT-1520 & subsp. kurstaki, crylAa $a^{+}$crylA $b^{+}$crylAc $c^{+}$cry $2^{+}$ & Laboratory stock \\
\hline WG-001 & Transformed strain of YBT-1520 by introducing pBMB 1808 & This study \\
\hline \multicolumn{3}{|l|}{ Plasmid } \\
\hline pBMB 1233 & Erm $^{\mathrm{r}} \mathrm{Amp}^{\mathrm{r}}$, res $^{+}$tnpI $^{++}$crylAcl $0^{+}$ori $^{+}$oriBt $^{+}, 8305 \mathrm{bp}$ & Wu et al., 2000 \\
\hline pBMB20-2 & Erm $^{\mathrm{r}} \mathrm{Amp}^{\mathrm{r}}$, p20 $^{+}$ori $^{+}$oriBt $^{+}, 10564 \mathrm{bp}$ & Shao et al., 2001 \\
\hline pBMB 1229 & Erm $^{\mathrm{r}} \mathrm{Amp}^{\mathrm{r}}$, res $^{+}$oriE $^{+}$oriBt $^{+}, 7274 \mathrm{bp}$ & Wu et al., 2000 \\
\hline pBMB 1200 & $\mathrm{Tc}^{\mathrm{r}} \mathrm{Amp}^{\mathrm{r}}$, tnpI ${ }^{+}$oriE $^{+}$oriBt $^{+}, 7078 \mathrm{bp}$ & Wu et al., 2000 \\
\hline pBMB 1801 & Erm $^{\mathrm{r}} \mathrm{Amp}^{\mathrm{r}}$, res $^{+}$tnpI $^{++}$ori $^{+}$oriBt $^{+}, 4534 \mathrm{bp}$ & This study \\
\hline pBMB 1803 & Erm $^{\mathrm{r}} \mathrm{Amp}^{\mathrm{r}}$, res $^{+}$crylAcl0 ${ }^{+}$oriE $^{+}$oriBt $^{+}, 10530 \mathrm{bp}$ & This study \\
\hline pBMB 1805 & $\mathrm{Erm}^{\mathrm{r}} \mathrm{Amp}^{\mathrm{r}}$, res $^{+}$tnpI' ${ }^{+}$cry $1 \mathrm{Ac} 10^{+}$p20 $0^{+}$oriE $^{+}$oriBt $^{+}, 5343 \mathrm{bp}$ & This study \\
\hline pBMB 1808 & $\mathrm{Erm}^{\mathrm{r}} \mathrm{Amp}^{\mathrm{r}}$, res $^{+}$crylAc10 $0^{+}$p $20^{+}$res $^{+}$tnpI ${ }^{+}$oriE $^{+}$oriBt $^{+}, 12601 \mathrm{bp}$ & This study \\
\hline pBMB 1811 & res $^{+}$crylAc10 $10^{+}$p20 $0^{+}$riBt $^{+}, 8339 \mathrm{bp}$ & This study \\
\hline pBMB1812 & Erm $^{\mathrm{r}} \mathrm{Amp}^{\mathrm{r}}$, res $^{+}$tnpI $^{++}$oriE $^{+}, 4362 \mathrm{bp}$ & This study \\
\hline
\end{tabular}

\footnotetext{
${ }^{\mathrm{a}} \mathrm{Erm}^{\mathrm{r}}$, erythromycin resistance; $\mathrm{Amp}^{\mathrm{r}}$, ampicillin resistance; $\mathrm{Tc}^{\mathrm{r}}$ tetracycline resistance; tnpI', truncated site-specific recombinase gene lacking 3 codons at its 3 ' terminus; tnpI, complete site-specific recombinase gene; res, resolution sites; oriE, the origin of replication of $E$. coli; oriBt, the origin of replication of B. thuringiensis. cry $1 A a$, cry $1 A b, c r y 1 A c 10$ and cry 2 are $B$. thuringiensis-harbored insecticidal genes; p20 is a gene encoding a $20-\mathrm{kDa}$ helper protein that was identified in B. thuringiensis subsp. israelensis strains.
}

\section{Construction of recombinant plasmids}

The recombinant plasmid pBMB1808 was constructed as follows (Fig. 1). Firstly, NdeI excision on plasmid pBMB1233 was performed to remove a 3771-bp of crylAc10 fragment, the remained larger fragment was self-ligated to generate the plasmid pBMB1801, crylAc10 fragment was further inserted into NdeI site of plasmid pBMB1229, resulting in plasmid pBMB1803 that contains the replicon of $B$. thuringiensis, one res of $\mathrm{Tn} 4430$, the replicon region of $E$. coli, and ampicillin and erythromycin resistance genes; Secondly, an 817-bp of KpnI/HindIII digested fragment from plasmid pBMB20-2, was inserted into the similar sites of plasmid pBMB1801, to generate plasmid pBMB1805 that containing one res region,
tnpI' and p20 that was controlled by the upstream crylC promoter (prolC); Finally, a 7258-bp of BamHI-digested fragment from plasmid pBMB1803 was inserted into plasmid pBMB1805 to give the plasmid pBMB1808. Apparently, in pBMB1808, the resident elements of $B$. thuringiensis, including crylAc10, the replicon of $B$. thuringiensis, p20 and prol $C$, were separated from non- $B$. thuringiensis elements such as ampicillin and erythromycin resistance genes, the $E$. coli replicon and tpnI', by two res fragments. Thus, pBMB1808 was designed to introduce a heterologous $p 20$ gene and to eliminate all of non- $B$. thuringiensis genes via TnpI-miediated sitespecific recombination in $B$. thuringiensis recipient. 


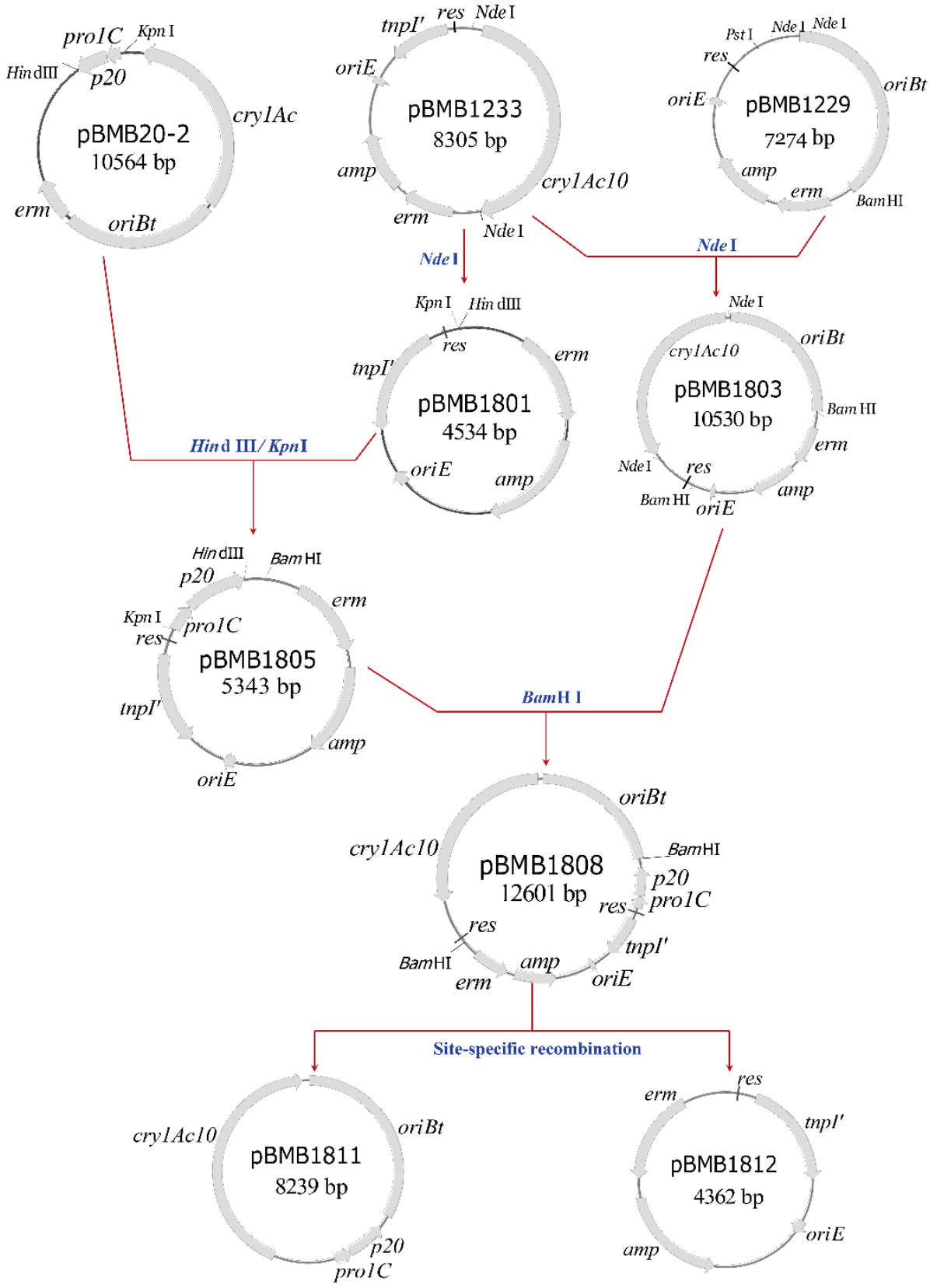

Fig. 1. Construction of recombinant plasmid pBMB1808 harboring the site-specific recombinant system.

Plasmid pBMB1808 resolves at two res sites in $B$. thuringiensis recipient, which results in pBMB1811 without antibiotic resistance genes, and pBMB1812 without $B$. thuringiensis replicon therefore the latter can not replicate in the recipient. $\mathrm{erm}^{r}$, erythromycin resistance gene; $a m p^{r}$, ampicillin resistance gene; tnpI', a truncated site-specific recombinase gene which lacking 3 codons at its 3' terminus; res, resolution sites; oriE, the origin of replication of $E$. coli; oriBt, the origin of replication of $B$. thuringiensis; prol $C$, the promoter of $c r y l C$ gene. The circles with boxes representing different plasmids are not shown to scale.

\section{Construction and screening of WG-001}

Recombinant plasmids were transformed into $E$. coli by standard procedures (Sambrook and Russell 2011). Transformation of B. thuringiensis by electroporation was performed as described previously (Shao et al. 2001). Screening of WG-001 was carried out by two steps. Firstly, the erythromycin-resistant colonies were screened by electro-transformation of pBMB1808 into wild-type strain YBT-1520, this was followed by an additional transformation with a helper plasmid, pBMB1200, as the donor DNA, and the tetracycline-resistant colonies were selected; Secondly, the tetracycline-resistant colonies were picked and inoculated numerically on 
LB plates, after incubation at $30{ }^{\circ} \mathrm{C}$ for $24 \mathrm{~h}$, the colonies were further inoculated on LB plates containing ampicillin and tetracycline, respectively, in the similar numerical order, to check their growth. The tetracycline- and erythromycin-sensitive colonies were thus obtained, and the GM B. thuringiensis WG001 strain was further identified from those colonies by PCR verification of $p 20$ gene and cryl-like genes, followed by checking plasmid profile and optical microscopic examination of crystals.

\section{Mass production of WG-001}

A seed culture of GM B. thuringiensis WG-001 grown at $30{ }^{\circ} \mathrm{C}$ for ten hours was used to provide an inoculum. The wettable powder of WG-001 was produced in a 40,000 liter merge fermenter by inoculating $1 \%(\mathrm{v} / \mathrm{v})$ seed culture and running the fermentation at $30{ }^{\circ} \mathrm{C}$ until $\sim 70 \%$ spore formation, followed by harvest of the cultures and rapid spray desiccation. All the parameters of the wettable powder of WG-001, such as the content of insecticidal proteins, toxicity against $H$. armigera larvae, $\mathrm{pH}$ value, moisture, suspension rate, wringing time and maximum particle size, were subsequently determined.

\section{Electron microscope}

Scanning electron microscope (SEM) observation of crystals was performed as previously described (Shao et al. 2001).

\section{Experimental field}

In a biennium, the environmental release of GM $B$. thuringiensis WG-001 was performed in a randomly selected natural cotton field in Mancheng county, Hebei province, China, where had never been treated with $B$. thuringiensis or other biopesticides. The cultivation, irrigation and fertilization were normally managed on demand of the crop growth and seasonal conditions. Two similar fields (each $\sim 40 \times 8 \mathrm{~m}$ ) separated by a $2 \mathrm{~m}$ of buffer zone were used as the trial and control fields for comparison of the pest-control effects. Other crops such as maize, tapioca, earthpea and vegetables were also planted nearby but were separated from the field by a buffer zone that was at least $2 \mathrm{~m}$ wide.

The cotton neonatal seedlings were fostered elsewhere and were replanted in April in the experimental field in rows separated by an $80-\mathrm{cm}-$ wide unplanted zones. Each seedling was separated from the other by $20-\mathrm{cm}$. Spray of the diluted suspension of WG-001 wettable powder onto the cotton plants were performed with a handle sprayer, the nozzle of the sprayer was kept about ten-cm above the top of the plants to allow WG-001 suspension sprinkling perpendicularly and evenly onto the leaves.

\section{Sampling}

Cotton leaf and soil samples were taken at 5 different times during the growing season: the $1^{\text {st }}, 2^{\text {nd }}$, $35^{\text {th }}, 36^{\text {th }}$ and $104^{\text {th }}$ day. The first day was selected and reckoned as the second larvae of cotton bollworms occurred initially in the experimental field (it was usually on the middle of April). Two time of spray with $70 \mathrm{~kg}$ of the 500-fold diluted suspension of WG001 wettable powder were successively performed on the $2^{\text {nd }}$ and the $36^{\text {th }} \mathrm{d}$. In parallel, the equivalent water was sprayed to cotton plants in the control field. On each sampling day, each about $50 \mathrm{~g}$ of soil was collected from the surface layer, and from five-, ten-, 15-, 20-, 25- and 30-cm deep soil layers, respectively, from five sample spots that were randomly selected but in symmetrical distribution across the field. Cotton leaves on each spot were also sampled at each sampling time, the upper, middle and the underside leaves of the growing cotton plants, were equivalently herborized. Moreover, samples of the surface-layer soils were also taken from each of six spots stretched the pilot and control field, over a maximum range of $50 \mathrm{~m}$ on four orientations. All samples were maintained at $4{ }^{\circ} \mathrm{C}$ and were promptly analyzed.

To determine the aerial dissemination range of WG-001 whilst spraying, 6 LB agar plates (each 15 $\mathrm{cm}$ in diameter) were placed on the periphery of the field in four orientations, either on the field land or pegged on the upper surface of plants. The plates were separated by $5 \mathrm{~m}$. Once spraying had started, the plates were opened to collect the dispersal strains, this was maintained for an additional 30 min even the spraying finished. The plates were then incubated for $48 \mathrm{~h}$ at $30^{\circ} \mathrm{C}$ and used for verification of the occurrence of WG-001.

\section{Population dynamics of total culturable bacteria, spore-forming bacilli and WG-001}

All soil samples were triturated in a mortar, and one gram of each treated sample was immersed into $100 \mathrm{ml}$ of sterile distilled water in a $250 \mathrm{ml}$ of Erlenmeyer flask containing 20 glass beads $(0.2 \mathrm{~mm}$ in diameter). After shaking vigorously for ten minutes, appropriate dilutions were plated on the selective medium. In parallel, the soil suspensions were incubated at $80{ }^{\circ} \mathrm{C}$ water bath with shaking (at $~ 100$ $\mathrm{rpm}$ ) for $30 \mathrm{~min}$, and then made the similar dilutions and platting to allow isolating the spore-forming bacilli. Plates thus obtained were incubated at $30{ }^{\circ} \mathrm{C}$ for $48 \mathrm{~h}$ then total bacterial CFUs and the sporeforming bacilli CFUs were counted respectively. The leaf samples were homogenized and each one gram obtained slurry was then diluted and plated as described above. The culturable filamentous fungi and yeast were also isolated by plating the diluted suspensions (without $80{ }^{\circ} \mathrm{C}$ water bath treatment) on the selective medium. To investigate the occurrence of WG-001 from various samples, the spore-forming bacilli were first isolated, and the single sporeforming bacilli colony was directly used for PCR analysis of $p 20$ and cryl-like genes by employing a rapid method as described by Ceron et al. (1994). WG-001 was identified as the positive amplified products of $p 20$, crylAa and crylAc were obtained 
simultaneously from one colony.

\section{DNA extraction and PCR manipulation}

Total DNA of single bacterial colonies was prepared as described by Wilson (1987). Rapid minipreparation of fungal DNA from single fungal isolates was performed as described by Liu et al. (2000). Total DNA of soil samples was extracted using UltraClean Soil DNA Kit (MoBio Laboratories, Solana Beach, CA). For screening of the GM WG-001 from the transformants with pBMB1808, and for tracking the occurrence of WG-001 amongst various samples, three separated PCR reactions were run by using the standard protocols (Sambrook and Russell 2011). One universal primer pairs, with sequences of 5'-GAGCCAAGCAGCTGGAGCAGTTTACACC3' (forward) and 5'-ATCACTGAGTCGCTTCGCATGTTTGACTTT CTC $-3^{\prime}$ (reverse) was used to specifically amplify the 724-bp crylAa fragment (Kalman et al. 1993); the second pairs, with sequences of 5'-TCACTTCCCATCGACATCTACC-3' (forward) and

\section{5'-ATCACTGAGTCGCTTCGCATGTTTGACTTT}

CTC $-3^{\prime}$ (reverse) was used to specifically amplify the 487-bp crylAc fragment, and the third primer pairs 5'-GGAGGATCCATGGGGACAGAAAATGGAGT G (forward) and CTTGAAAGCTTAAACGTTCCG-3' (reverse) to amplify the 585-bp p20 gene (Liu et al. 1999). PCR reactions were also employed to verify the possible gene transfer of cryl-like genes.

\section{Bioassay and evaluation of pest-control effects in fields}

For determining the lepidopterancidal potency, bioassay of WG-001 preparations (the fermentation emulsion or the wettable powder) against neonate larvae of $H$. armigera bred artificially in the laboratory, was performed as described previously (Shao et al. 2001). In order to evaluate the control effect on cotton bollworms by WG-001 in the trial field, 15 randomly selected cotton plants from the trail field, were plotted to enumerate the ovum and larva of $H$. armigera, before and one, three, and five days after the treatment of WG-001 suspension. The parallel experiments were performed in the control field. Furthermore, the occurrence of non-target pests (Aphis gossypii and Tetranychus telarius) and several beneficial insects such as Coccinella spp., Chrysopa sinica, Araneu cornutus and Xylocoris galactinus in the trial field and the control field were also investigated by the direct enumeration of the survival insects, from random selected 20 cotton plants in the trial and control field after spraying WG-001 suspension (in the trial field) or water (in the control field) in $0,1,3$ and $15 \mathrm{~d}$.

\section{Statistics}

All data obtained were averaged and logtransformed, and were statistically analyzed using SAS/STAT software, version 6.11 (Statistical Analysis
Systems, SAS Institute, Cary, N.C.). The triplicate enumeration of insects of the fields was calculated for the pest-control effect, and was asin-transformed for analysis of variance (ANOVA) and tested by LSD (Least Significant Difference).

\section{Results and discussion}

\section{Construction and mass production of GM WG-001}

GM WG-001 strain was obtained by introducing the recombinant plasmid pBMB1808 into wild-type strain YBT-1520 and by PCR screening of transformed colonies. Theoretically, under TnpIdirected site-specific recombination, transformantbearing pBMB1808 resolves into two derivative products, pBMB1811 and pBMB1812. Plasmid pBMB1811 contains crylAc10, p20, and the $B$. thuringiensis replicon, but is free of any antibiotic resistance gene, whereas pBMB1812 contains tnpI' (a truncated tnpI lacking 3 codons at its 3 ' terminus), the E. coli replicon, and erythromycin/ampicillin resistance genes (Fig. 1). Plasmid pBMB1812 is unable to replicate synchronously and is therefore lost from $B$. thuringiensis recipients, thus WG-001 harbors pBMB1811 and all resident plasmids that carry cry genes. In the experiment, the erythromycin-resistant colonies carrying pBMB1808 were firstly screened at a transformation frequency of $\sim 10^{2}$ transformants per $\mu \mathrm{g}$ donor DNA, but unexpectedly, by picking the erythromycin-resistant colonies into LB agar for incubation, no erythromycin-sensitive colony could be detectable although a successive inoculation was performed. It appeared that the intact pBMB1808 was maintained in the recipient, probably the truncated tnpI' was not functioning or expressed very weak. To facilitate pBMB1808's resolving, an unstable plasmid carrying the complete tnpI and tetracycline-resistant gene, pBMB1200, was additionally transferred into the erythromycin-resistant transformant that screened previously. The tetracycline-resistant transformants thus obtained were further incubated on LB plates, followed by detecting their growth on erythromycinand tetracycline-resistant agar. As a result, in all detected colonies grown on LB agar, about $85 \%$ colonies were erythromycin- and tetracyclinesensitive. Several colonies were further selected to verify the plasmid profile, and GM WG-001 was thus obtained amongst them. The presence of crylAa, crylAc and an additional $p 20$ gene and selective elimination of heterologous antibiotic resistance genes in WG-001 strain were confirmed by PCR and endonuclease digestion analysis of the amplified fragment.

Stationary phase WG-001 culture was examined by microscopy. Its bipyramidal crystals were much larger than its parent strain, YBT-1520 (Fig. 2A, Fig. $2 \mathrm{~B})$, and the crystals occupied most of the intracellular space and pushed spores to the opposite sides of the cells (Fig. 2C). SDS-PAGE analysis and protein quantification of Cry proteins demonstrated that $\mathrm{a} \sim 2$ - 
fold increase of total Cry proteins in WG-001 compared to YBT-1520 (Fig. 2D), suggesting that P20 expressed in WG-001 exerted a significant effect on Cry protein synthesis and crystal formation.
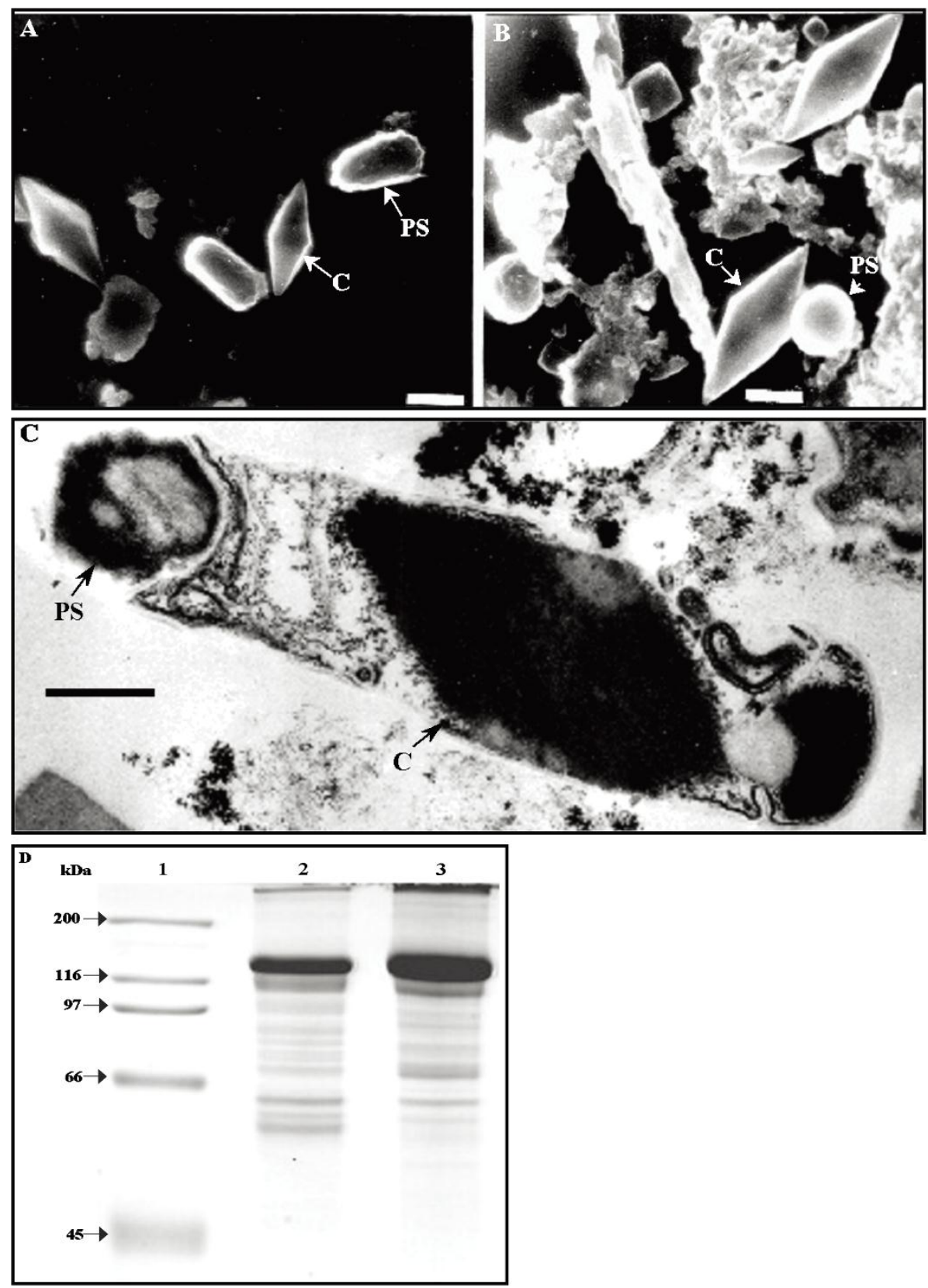

Fig. 2. Electron micrographs of spores and crystals, and SDS-PAGE analysis of insecticidal crystal proteins produced by YBT-1520 and WG-001. (A) preparation of YBT-1520; (B) preparation of WG-001; (C) one cell of WG-001; (D) Lane 1, standard protein markers; lane 2, YBT-1520; lane 3, WG-001. For SEM observation, bacteria were cultivated in liquid ICPM medium, free crystals and spores, or the cells at the stationary phase, were washed and ion coated. PS: parasporal body; C: crystal. Bars: $1 \mu \mathrm{m}$.

WG-001 wettable powder was produced on an industrial scale. WG-001 strain grew prosperously in the optimized fermentative medium, which covered a $31 \mathrm{~h}$ running time in merge fermentation. Bioassay of the final fermentation emulsion gave a lepidopterancidal potency of $4200 \mathrm{IU} \mu \mathrm{l}^{-1}$, which was increased by $25 \%$ compared to the fermentation of YBT-1520. The lepidopterancidal potency of the WG001 wettable powder product was finally modulated to be $16,000 \mathrm{IU} \mathrm{mg} \mathrm{m}^{-1}$, to comparatively evaluate the insecticidal effect in the pilot trials with other $B$. thuringiensis commercial products that have similar specifications.

\section{Effect on cotton pests and non-target insects}

Pilot trials in the cotton field for evaluating the lepidopterancidal effect of WG-001 wettable powder were carried out, as shown in Table 2. The average 
effects of controlling $H$. armigera $2^{\text {nd }}$ larva in one day treated by WG-001 suspension were lower than that by the chemical insecticide but there were no significant differences in $5 \mathrm{~d}$, whereas WG-001 was almost equivalent to the commercial B. thuringiensis wettable powder product. Examination of the dynamics of several non-target pests and beneficial insects showed that WG-001 did not exert a notable effect on the numbers and the community structure of these arthropods (Table 3). In contrast, non-target pests and beneficial insects were decreased synchronously by treating with the chemical insecticide, revealing that although the $H$. aemigera larva had largely declined when acted on by WG-001 suspension, surviving non-target pests such as Aphis gossypii and Tetranychus telarius could feed the beneficial insects maintaining the communities at a stable level.

Table 2. Control effects of WG-001 and other pesticides against the $2^{\text {nd }}$ larvae of $H$. armigera in the pilot trials.

\begin{tabular}{|c|c|c|c|c|c|c|c|}
\hline \multirow[t]{3}{*}{ Pesticides } & \multirow[t]{3}{*}{ Dilutions } & \multicolumn{6}{|c|}{ Total control effects $(\%)^{a}$} \\
\hline & & \multicolumn{3}{|c|}{ The first year } & \multicolumn{3}{|c|}{ The second year } \\
\hline & & $1 \mathrm{~d}$ & $3 \mathrm{~d}$ & $5 \mathrm{~d}$ & $1 \mathrm{~d}$ & $3 \mathrm{~d}$ & $5 \mathrm{~d}$ \\
\hline \multirow[t]{2}{*}{ WG-001 } & $500 \times$ & $60.0 \pm 7^{b}$ & $81.3 \pm 5$ & $81.0 \pm 9$ & $70.1 \pm 3$ & $85.6 \pm 5$ & $88.2 \pm 4$ \\
\hline & $800 \times$ & $54.7 \pm 6$ & $76.0 \pm 7$ & $76.6 \pm 11$ & $65.2 \pm 5$ & $80.5 \pm 8$ & $83.6 \pm 7$ \\
\hline \multirow{2}{*}{$\begin{array}{l}\text { Bt-Wettable } \\
\text { Powder }^{c}\end{array}$} & $500 \times$ & $57.6 \pm 3$ & $77.3 \pm 2$ & $80.3 \pm 5$ & $66.6 \pm 4$ & $79.8 \pm 3$ & $87.4 \pm 1$ \\
\hline & $800 \times$ & $55.7 \pm 5$ & $74.0 \pm 7$ & $71.4 \pm 3$ & $\mathrm{ND}^{\mathrm{d}}$ & ND & ND \\
\hline Methamidophos ${ }^{\mathrm{e}}$ & $800 \times$ & $87.1 \pm 4$ & $77.5 \pm 5$ & $74.3 \pm 5$ & ND & ND & ND \\
\hline Cypermethrin $^{\mathrm{f}}$ & $800 \times$ & ND & ND & ND & 91.1 & 95.7 & 89.1 \\
\hline Water $^{\mathrm{g}}$ & - & $5.2 \pm 5$ & $3.8 \pm 4$ & $4.5 \pm 3$ & $6.6 \pm 5$ & $5.4 \pm 5$ & $5.6 \pm 4$ \\
\hline
\end{tabular}

Note: ${ }^{a}$ Data were averaged from triplications of statistics of pilot trials; ${ }^{\mathrm{b}}$ Mean \pm standard deviation; ${ }^{\mathrm{c}} \mathrm{A}$ B. thuringiensisbased commercial biopesticide with a lepidopterancidal potency of $16,000 \mathrm{IU} \mathrm{mg}^{-1}$, which was produced in Hubei BT R \& D Center, Wuhan, China; ${ }^{\mathrm{d}} \mathrm{ND}$, not determined; ${ }^{\mathrm{e}} 50 \%$ latex; ${ }^{\mathrm{f}} 22 \%$ latex; ${ }^{\mathrm{g}}$ the negative control.

Table 3. Enumeration of pests and several beneficial insects in cotton fields after applying WG-001 and cypermethrin.

\begin{tabular}{|c|c|c|c|c|c|c|c|c|c|c|c|c|}
\hline \multirow{3}{*}{ Insects } & \multicolumn{12}{|c|}{ Populations of the survival insects ${ }^{a}$} \\
\hline & \multicolumn{3}{|c|}{$0(d)^{b}$} & \multicolumn{3}{|c|}{$1(\mathrm{~d})$} & \multicolumn{3}{|c|}{$3(d)$} & \multicolumn{3}{|c|}{$15(\mathrm{~d})$} \\
\hline & WG & CY & $\mathrm{NC}$ & WG & $\mathrm{CY}$ & $\mathrm{NC}$ & WG & $\mathrm{CY}$ & $\mathrm{NC}$ & WG & $\mathrm{CY}$ & $\mathrm{NC}$ \\
\hline Pests & & & & & & & & & & & & \\
\hline H. armigera & $9 \pm 1^{c}$ & $7 \pm 1$ & $10 \pm 1$ & $8 \pm 2$ & $5 \pm 1$ & $63 \pm 4$ & $10 \pm 2$ & $3 \pm 0$ & $73 \pm 2$ & $15 \pm 2$ & $26 \pm 3$ & $42 \pm 4$ \\
\hline $\begin{array}{l}\text { Aphis } \\
\text { gossypii }\end{array}$ & $52 \pm 3$ & $65 \pm 2$ & $51 \pm 5$ & $67 \pm 8$ & $0 \pm 0$ & $\begin{array}{l}72 \pm \\
12\end{array}$ & $\begin{array}{l}78 \pm \\
11\end{array}$ & $0 \pm 0$ & $82 \pm 4$ & $\begin{array}{l}128 \pm \\
13\end{array}$ & $\begin{array}{l}152 \pm \\
15\end{array}$ & $\begin{array}{l}137 \pm \\
21\end{array}$ \\
\hline $\begin{array}{l}\text { Tetranychus } \\
\text { telarius } \\
\text { Beneficial } \\
\text { insects }\end{array}$ & $8 \pm 2$ & $10 \pm 2$ & $16 \pm 2$ & $15 \pm 1$ & $0 \pm 0$ & $22 \pm 2$ & $23 \pm 2$ & $0 \pm 0$ & $30 \pm 5$ & $46 \pm 7$ & $63 \pm 7$ & $58 \pm 5$ \\
\hline $\begin{array}{l}\text { Coccinella } \\
\text { spp. }\end{array}$ & $13 \pm 2$ & $12 \pm 1$ & $11 \pm 1$ & $11 \pm 1$ & $1 \pm 0$ & $14 \pm 2$ & $12 \pm 8$ & $0 \pm 0$ & $15 \pm 5$ & $26 \pm 9$ & $5 \pm 2$ & $31 \pm 6$ \\
\hline $\begin{array}{l}\text { Chrysopa } \\
\text { sinica }\end{array}$ & $1 \pm 0$ & $3 \pm 0$ & $2 \pm 0$ & $1 \pm 0$ & $0 \pm 0$ & $1 \pm 1$ & $4 \pm 0$ & $0 \pm 0$ & $9 \pm 3$ & $10 \pm 2$ & $3 \pm 1$ & $8 \pm 2$ \\
\hline $\begin{array}{l}\text { Araneu } \\
\text { cornutus }\end{array}$ & $10 \pm 4$ & $8 \pm 3$ & $7 \pm 2$ & $9 \pm 4$ & $0 \pm 0$ & $8 \pm 6$ & $10 \pm 8$ & $0 \pm 0$ & $10 \pm 7$ & $13 \pm 6$ & $2 \pm 1$ & $17 \pm 4$ \\
\hline $\begin{array}{l}\text { Xylocoris } \\
\text { galactinus }\end{array}$ & $0 \pm 0$ & $0 \pm 0$ & $0 \pm 0$ & $0 \pm 0$ & $0 \pm 0$ & $1 \pm 0$ & $4 \pm 1$ & $2 \pm 1$ & $1 \pm 1$ & $2 \pm 0$ & $1 \pm 0$ & $2 \pm 2$ \\
\hline
\end{tabular}

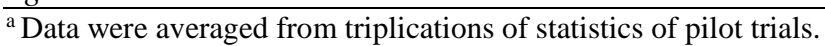

${ }^{b}$ The time after application of WG-001 or cypermethrin. WG., WG-001; CY, cypermethrin; NC, negative control.

c Mean \pm standard deviation.

\section{The dissemination ranges of WG-001 strains}

The aerial dissemination ranges of WG-001 strains driven by wind power were determined. It showed that the maximum range was $15 \mathrm{~m}$ towards the downwind orientation (east), contrary to a minimal range of $5 \mathrm{~m}$ towards the north, the upwind orientation. Additionally, since only 2-6 WG-001 colonies were found on each detector plate, which taking a proportion of $75-100 \%$ of total spore-forming bacilli isolates, this suggests that under the manipulative mode of spray of WG-001, wind power did not conduct a notable dissemination.

The surface-layer soil and leaf samples taken from the periphery plots of the cotton field were performed to re-isolate the WG-001 strain. Coincidently, no WG001 isolate had been detected in all samples that were taken in different times and plots, indicating that the aerial dissemination of WG-001 overflowing the trial 
field was rather limited and might be beyond the detection limit.

The soil samples taken from the trial field at different depths were used to trace the vertical dissemination range of WG-001. WG-001 was only found to occur in surface-layer soil and 5-cm-depth soil samples. This result could be explained if the spray of WG-001 was mainly on cotton leaves and less WG-001 dropped to the fleet soil by gravity.

\section{Survival of WG-001 on the leaf surface and in soil}

On each spray date, introduction of GM WG-001 onto the leaf surface resulted in establishment of a population of $10^{6}$ total bacterial cells per $g$ of fresh leaves (Fig. 3A). Each 20 randomly selected colonies from one plate (the colony numbers was modulated to $\sim 60-100$ of each plate by dilution) were tested by PCR, that they all were WG-001, suggesting that WG-001 was at high level in the populations. However, WG001 decreased to 0 level by 34 days after the first release, and by 68 days after the second release, indicating WG-001 did not establish a constant colonization on cotton leaf surfaces although a supplementary introduction was given.
Soil samples taken from different plots of the field were used to sort bacilli isolates and followed by PCR detection for WG-001. It was found that the introduced population did not establish in the soil of the field, except a few WG-001 isolates occurred in the surface-layer and 5-cm-depth soil samples, indicating that the introduced WG-001 was probably unable to compete for niche colonization with active indigenous microbial communities. We also tested the survival of the introduced WG-001 in the potted condition, in which Chinese cabbage was planted in the soil taken from the trial field (to allow similar humus conditions), and watering was controlled to sop the soil from the bottle of the garden pot. As shown in Fig. 3B, the population of the total bacilli-like bacteria remained relatively constant with $\sim 10^{6} \mathrm{CFU} \mathrm{g}{ }^{-1}$ of dry soil after the initial $15 \mathrm{~d}$, which then dropped to $\sim 10^{5}$ CFU g ${ }^{-1}$ of dry soil at 45 days and then maintained this level till 90 days after spraying. This result confirmed that the fate of GM bacteria in laboratory conditions could differ from that in field conditions (Viebahn et al. 2003), in which the weather, watering and activities of other organisms could exert a significant influence.
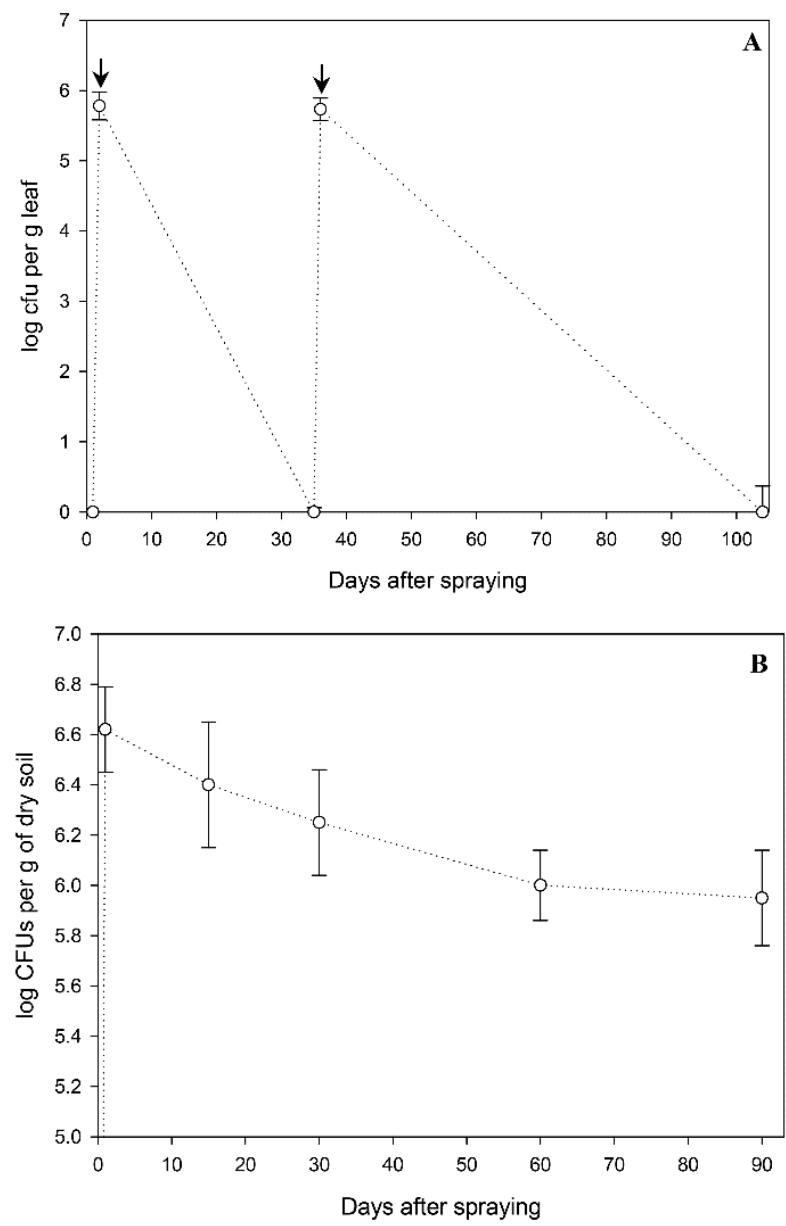

Fig. 3. Population dynamics for total bacilli-like bacteria on cotton leaves of the field (A) and the potted soils (B). In A, WG-001 was sprayed twice, the arrows indicate the spraying days which were the $2^{\text {nd }}$ and the $36^{\text {th }} \mathrm{d}$, respectively. In $\mathrm{B}$, the experiment was performed under the laboratory condition, soils were taken from the same trial field as A, and Chinese cabbage was planted. 
Effects of WG-001 on culturable indigenous microbial populations in soils

The effects of WG-001 on the culturable indigenous bacterial and filamentous fungal populations were preliminarily investigated by counting the $\mathrm{CFU}$ numbers of the re-isolated microflora on selective medium. As shown in Fig. 4A and $4 \mathrm{~B}$, despite the introduction of $\mathrm{WG}-001$ in the experimental field, no statistically significant differences of total re-isolated bacteria and filamentous fungi were found from soil plots. This was consistent with the result of re-isolation of WG001 from the soil samples, which revealed only few WG-001 strains pierced into the soil environment since WG-001 was mainly sprinkled onto the leaves.
To further assess the effect of introduced WG-001 on the indigenous microflora of soil environment, a parallel experiment was performed under the potted condition in the greenhouse, in which WG-001 800fold diluted suspensions were sprinkled directly onto plotted cotton plants and soils that taken from the experimental field. As shown in Fig. 4C and 4D, total culturable bacteria CFUs did not change drastically by comparing WG-001 treated soils with the control, and it revived to the original level by 90 days after spraying of WG-001 suspension, whereas a slight effect on indigenous fungal CFUs were observed, suggesting that the extraneous GM WG-001 had no significant biological influence on the indigenous microflora .
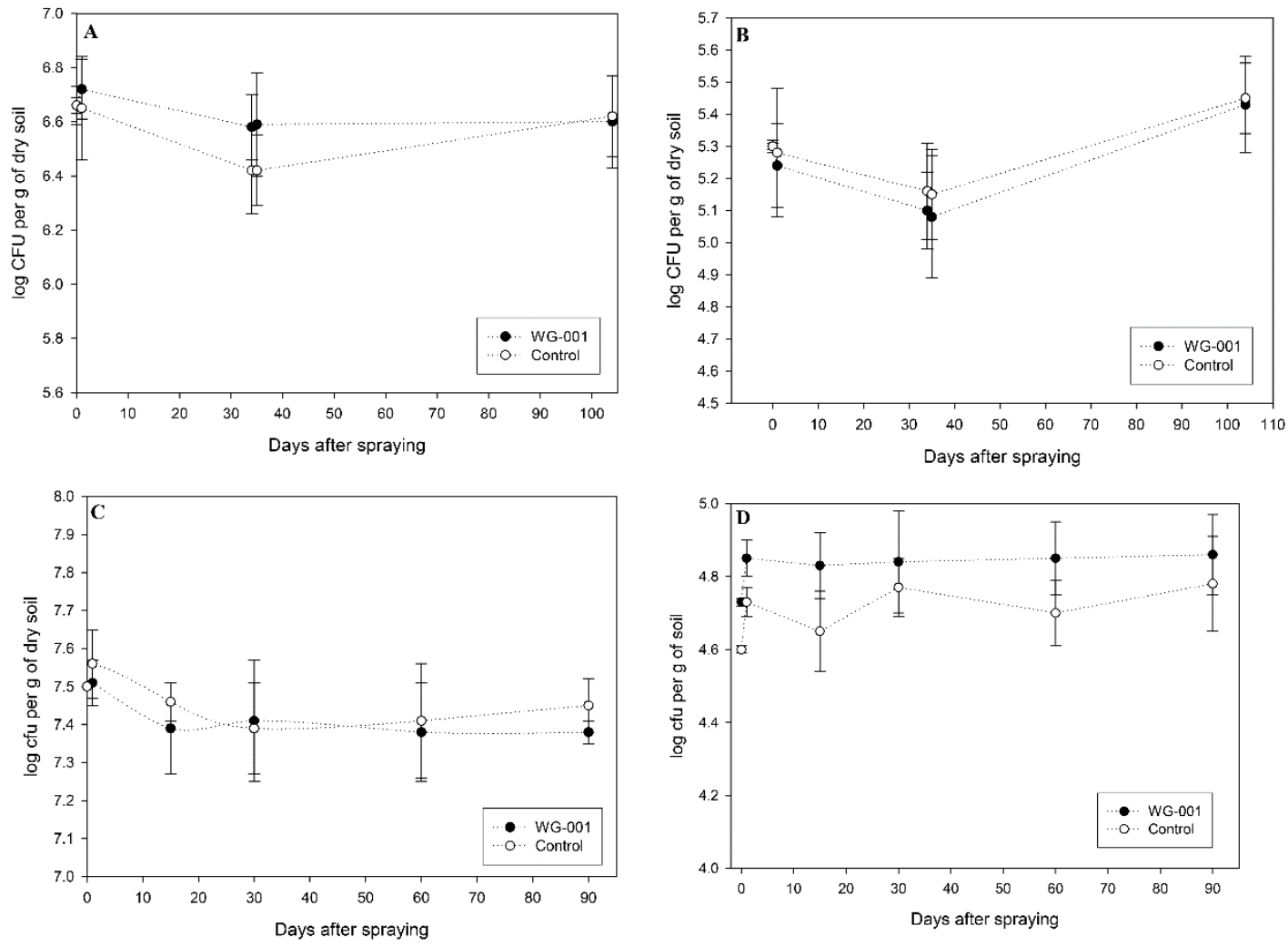

Fig. 4. Effects of WG-001 on population of the indigenous microflora. A, on population of total bacterial community of the cotton field; B. on population of fungi of the cotton field; C, on population of total bacteria of the potted soil; D, on population of fungi of the potted soil.

\section{Preliminary evaluation of plasmid transfer and} horizontal gene transfer

The transfer of plasmid pBMB1811 from WG-001 to indigenous bacteria, and the potential horizontal gene transfer of crylAa, crylAc and $p 20$ from WG001 to fungi or plant leaves, were detected by PCR amplification of the relevant genes and plasmid profiling analysis of the cells. Among 513 randomly selected bacterial colonies that were taken at the sampling days, only 3 bacterial colonies were verified to carry the crylAa, crylAc, and p20 genes together but without the appearance of the single gene. By further plasmid profiling analysis of the positive colonies, we confirmed these three colonies were WG001 itself. Moreover, 138 fungal colonies and 41 cotton leaf samples were also detected by PCR, this revealed that there was no appearance of neither crylike nor $p 20$ genes.

In the natural environment, the dissemination range and capability of the introduced GM bacteria are affected mainly by spray techniques, application area, weather conditions, and various organisms dwelling in the area such as insects and vertebrates, worms and parasites. On the other hand, there appears to be an initial decline in the population of the introduced GM bacteria after which it is maintained at a constant level 
in natural soils, and a transient effect on the indigenous microflora due to predation, presence of bacteriophages, growth inhibitors and competition with the indigenous microflora for an ecological niche (Viebahn et al. 2003). In this work, under the manipulative spray mode and action dose that was competent in pest-control, the wind power did not contribute significantly to the aerial dissemination of WG-001, and the reduced rainfall in the days following spraying was also shown not to help in the vertical dispersal from the cotton leaves to the soils. Therefore it was observed that no notable overflow or contamination of WG-001 to either soils or outside areas of the field occurred. Although the impact of the dwelling organisms on the potential dissemination of WG-001 was not investigated, the fact that the application of GM $B$. thuringiensis biopesticide can be manipulated depending on the weather and pest harm condition, we note that the likelihood of dissemination and contamination of the introduced WG-001 to nontarget organisms could be consequently minimized. Additionally, the introduced WG-001 strain showed a limited capability of colonization as the extraneous bacteria, and was apparently unable to develop into a dominant microbial community, and in turn, the population of WG-001 dropped rapidly, possibly by forming spores or turned into a viable but nonculturable (VBNC) state.

\section{Conclusions}

An environmentally friendly GM B. thuringiensis WG-001 strain with a significant increase of total Cry protein was constructed. When released in cotton field, WG-001 showed its efficacy in pest-control. No evidence supports that WG-001 had a significant impact on the cotton-field microcosm. Thus, this work provides a background study for the potential future application of WG-001 as a commercial biopesticidal agent.

\section{Acknowledgements}

We are grateful to Fan Xiuhua and Wang Rongyan for their kind technical assistances, Zhang Zhenyu, $\mathrm{Wu}$ Xiaoming and Ren Hongyan for their helps in partial experiments. This work was supported by National Natural Science Foundation of China (item no. 31570123), and a grant from the Chinese National Project for the Development of Science \& High Technology (item 2001AA212301).

\section{References}

Ceron J, Covarrubias L, Quintero R, Ortiz A, Ortiz M, Aranda E, Lina L, Bravo A (1994) PCR analysis of the cryI insecticidal crystal family genes from Bacillus thuringiensis. Appl Environ Microbiol, 60: 353 .

Dervyn E, Poncet S, Klier A, Rapoport G (1995) Transcriptional regulation of the cryIVD gene operon from Bacillus thuringiensis subsp. israelensis. J Bacteriol, 177: 2283.

Federici BA. 2005. Insecticidal bacteria: an overwhelming success for invertebrate pathology. J Invertebr Pathol 89: 30.

Jouzani GS, Valijanian E, Sharafi R (2017) Bacillus thuringiensis: a successful insecticide with new environmental features and tidings. Appl Microbiol Biotechnol, 101: 2691.

Kalman S, Kiehne KL, Libs JL, Yamamoto T (1993) Cloning of a novel cryIC-type gene from a strain of Bacillus thuringiensis subsp. galleriae. Appl Environ Microbiol, 59: 1131.

Lawler SP (2017) Environmental safety review of methoprene and bacterially-derived pesticides commonly used for sustained mosquito control. Ecotoxicol Environ Safe, 139: 335.

Li L, Chen Z, Yu ZN (2017) Mass production, application and market development of Bacillus thuringiensis biopesticides in China. In: Fiuza LM, Polanczyk RA, Crickmore N (eds), Bacillus thuringiensis and Lysinibacillus sphaericus. Springer International Puslishing AG, 2017, pp. 185-212.

Li L, Yu ZN (2012) Genetically modified Bacillus thuringiensis biopesticides. In: Sansinenea E (ed), Bacillus thuringiensis biotechnology, Springer Science/Business Media B.V., 2012. pp. 231-258.

Liu D, Coloe S, Baird R, Pederson J (2000) Rapid mini-preparation of fungal DNA for PCR. J Clin Microbiol, 38: 471.

Liu ZD, Sun M, Chen YH, Yu ZN, Manassherob R, Ben-Dov E, Zaritsky A (1999) The influence of the $20 \mathrm{kDa}$ protein from Bacillus thuringiensis subsp. israelensis on the cytolytic activity of CytA. Acta Gen Sin, 26: 81.

Melo AL, Soccol VT, Soccol CR (2016) Bacillus thuringiensis: mechanism of action, resistance, and new applications: A review. Crit Rev Biotechnol, 36: 317.

Palma L, Munoz D, Berry C, Murillo J, Caballero $P$ (2014) Bacillus thuringiensis toxins: An overview of their biocidal activity. Toxins (Basel), 6: 3296.

Sambrook J, Russell DW (2011) Molecular cloning: A laboratory manual, 3rd ed. Cold Spring Harbor Laboratory Press, Cold Spring Harbor, N.Y.

Sanchis V, Agaisse H, Chaufaux J, Lereclus D (1997) A recombinase-mediated system for elimination of antibiotic resistance gene markers from genetically engineered Bacillus thuringiensis strains. Appl Environ Microbiol, 63: 779.

Shao Z, Liu Z, Yu ZN (2001) Effects of the 20kilodalton helper protein on Cry1Ac production and spore formation in Bacillus thuringiensis. Appl Environ Microbiol, 67: 5362.

Siegwart M, Graillot B, Blachere Lopez C, Besse S, Bardin M, Nicot PC, Lopez-Ferber M (2015) Resistance to bio-insecticides or how to enhance their sustainability. A review. Front Plant Sci, 6: 381. 
Singh AK, Dubey SK (2016) Current trends in Bt crops and their fate on associated microbial community dynamics: A review. Protoplasma, 253: 663.

Sun M, Liu Z, Yu ZN (2000) Characterization of the insecticidal crystal protein genes of Bacillus thuringiensis YBT-1520. Acta Microbiol Sin, 40: 365.

Thomas DJ, Morgan JA, Whipps JM, Saunders JR (2001) Plasmid transfer between Bacillus thuringiensis subsp. israelensis strains in laboratory culture, river water, and dipteran larvae. Appl Environ Microbiol, 67: 330.

Venter HJ, Bohn T (2016) Interactions between Bt crops and aquatic ecosystems: A review. Environ Toxicol Chem, 35: 2891.

Viebahn M, Glandorf DC, Ouwens TW, Smit E, Leeflang P, Wernars K, Thomashow LS, van Loon LC, Bakker PA (2003) Repeated introduction of genetically modified Pseudomonas putida WCS358r without intensified effects on the indigenous microflora of field-grown wheat. Appl Environ Microbiol, 69: 3110.

Vilas-Boas G, Sanchis V, Lereclus D, Lemos MV, Bourguet D (2002) Genetic differentiation between sympatric populations of Bacillus cereus and Bacillus thuringiensis. Appl Environ Microbiol, 68: 1414.

Wilson K (1987) Preparation of genomic DNA from bacteria, In Current Protocols in molecular Biology ed. Ausubel, F.M., Brent, R., Kingston, R.E., Moore, D.D., Smith, J.A., Seidman, J.G., and Struhl, K. pp. 2.4.1, 2.4.2. Wiley, New York.

Wu D, Federici BA (1993) A 20-kilodalton protein preserves cell viability and promotes CytA crystal formation during sporulation in Bacillus thuringiensis. J Bacteriol, 175: 5276.

Wu D, Federici BA (1995) Improved production of the insecticidal CryIVD protein in Bacillus thuringiensis using cryIA $(c)$ promoters to express the gene for an associated 20-kDa protein. Appl Microbiol Biotechnol, 42: 697.

Wu L, Sun M, Yu ZN (2000) A new resolution vector with crylAc10 gene based on Bacillus thuringiensis transposon Tn4430. Acta Microbiol Sin, 40: 264.

Yaqoob A, Shahid AA, Samiullah TR, Rao AQ, Khan MA, Tahir S, Mirza SA, Husnain T (2016) Risk assessment of $\mathrm{Bt}$ crops on the non-target plant-associated insects and soil organisms. J Sci Food Agric, 96: 2613. 
